\title{
PERUBAHAN PENGATURAN PERUNTUKAN KAWASAN DALAM HUKUM PENATAAN RUANG (Studi Politik Hukum Atas Kebijakan Penataan Ruang Kota Malang)
}

\author{
Tulus Wahjuono \\ Pascasarjana Fakultas Hukum Universitas Brawijaya \\ dejureuinmalang@gmail.com
}

\begin{abstract}
This research aims to analyze the changes of area designation rule of spatial law in Malang, its causes, and its implications for legal politics. This research used a juridical-empirical approach. Data analyzed using interactive and content analysis. The results showed that the changes of area designation rule of spatial law in Malang based on a factors of spatial law issues and its deviation in the field, both legal and non-legal condition. The changes of area designation rule of spatial law in Malang which are not based on the principle of good environmental governance had an impact on legal politics that not aligned the product of spatial law to both progressive law nor responsive law. It will lose its legitimacy, either philosophical, juridical, and sociological in the society.

Penelitian ini bertujuan menganalisis perubahan aturan peruntukan kawasan dalam hukum penataan ruang di Kota Malang, faktor penyebab, dan implikasinya terhadap politik hukum. Penelitian ini menggunakan pendekatan yuridis-empiris. Data penelitian dianalisis menggunakan model analisis interaktif dan analisis isi. Hasil penelitian menunjukkan bahwa perubahan aturan peruntukan kawasan dalam hukum tata ruang Kota Malang didasari oleh faktor permasalahan penataan ruang dan faktor deviasi RTRW di lapangan, baik yang bersifat hukum maupun non-hukum. Perubahan aturan peruntukan kawasan dalam hukum penataan ruang Kota Malang yang belum mendasarkan pada prinsip good environmental governance membawa dampak terhadap politik hukum yaitu tidak selarasnya produk hukum penataan ruang yang dihasilkan dengan konsep hukum progresif dan hukum responsif serta kehilangan legitimasinya, baik secara filosofis, yuridis maupun sosiologis di dalam masyarakat.
\end{abstract}

Kata Kunci : Politik, Hukum, Peruntukan, Tata Ruang

Perwujudan keadilan sosial di bidang pertanahan dapat dilihat dari prinsip-prinsip dasar $\mathrm{UUPA}^{1}$, yakni prinsip 'negara menguasai', prinsip penghormatan terhadap hak atas tanah masyarakat hukum adat, asas fungsi sosial semua hak atas tanah, prinsip landreform, prinsip perencanaan dalam penggunaan tanah dan upaya pelestariannya, dan prinsip nasionalitas. Prinsip dasar tersebut kemudian dijabarkan dalam berbagai produk berupa peraturan perundang-undangan dan kebijakan

1 Undang-undang Nomor 5 Tahun 1960 tentang Peraturan Dasar Pokok-Pokok Agraria (Lembaran Negara Tahun 1960 Nomor 104, Tambahan Lembaran Negara Nomor 2043). lainnya. ${ }^{2}$ Salah satu peraturan perundang-undangan yang menjabarkan prinsip-prinsip tersebut adalah Undang-Undang Nomor 24 Tahun 1992 tentang Penataan Ruang (UUPR 1992). ${ }^{3}$

Karakteristik yang menarik dari UUPR 1992 dibandingkan dengan peraturan perundangundangan yang lain adalah berbentuk suatu rencana (perencanaan) dan dapat ditinjau kembali secara berkala sehingga memungkinkan adanya suatu

2 Sumardjono dalam "Reorientasi Kebijakan Pertanahan," Kompas, September 1994 dikutip dari Sumardjono, Maria S.W. 2005. Kebijakan Pertanahan: Antara Regulasi dan Implementasi. Jakarta: Kompas, hlm. 42-43.

${ }^{3}$ Pada tanggal 26 April 2007 diundangkan UU No.26 Tahun 2007 tentang Penataan Ruang. 
perubahan pengaturan didasarkan dinamika sosial masyarakat. Berpedoman pada Pasal 22 Ayat (3) UUPR 1992, Kota Malang menetapkan rencana tata ruang wilayah dalam bentuk peraturan daerah ${ }^{4}$ pada tanggal 21 Agustus 2001 dan diundangkan dalam Lembaran Daerah Kota Malang Tahun 2001 No. 10/C, yakni Peraturan Daerah Kota Malang Nomor Tahun 2001 tentang Rencana Tata Ruang Wilayah Kota Malang Tahun 2001-2011. ${ }^{5}$

Berlandaskan Perda RT RW Tahun 2001 tersebut, terdapat fakta dalam pembangunan beberapa kawasan di Kota Malang, telah terjadi penyimpangan terhadap ketentuan perda tersebut. Adanya penyimpangan pada awalnya de facto secara fisik telah mengubah peruntukan suatu kawasan tanpa dibarengi dengan perubahan pengaturan yuridisnya. Sedangkan secara hukum, perubahan pengaturan peruntukan kawasan, dapat dilihat dari penerbitan Peraturan Walikota Malang Nomor 33 Tahun 2005 tentang Rencana Detail Tata Ruang Kota Kecamatan Klojen Tahun 2005-2008 ${ }^{6}$ yang dalam beberapa kebijakan merupakan penyimpangan atau perubahan terhadap pengaturan peruntukan kawasan yang diatur dalam Perda RT RW Kota Malang Tahun 2001, di samping terdapat kepentingan umum yang dilanggar yang salah satunya adalah hilangnya akses publik dalam penataan ruang. Budihardjo menyebutnya dengan ruang publik (public space $)^{7}$, yaitu tempat para warga melakukan kontak sosial dan telah terjadi ketidaksinkronan antara pengaturan yang satu dengan yang lain, baik dari segi derajat (hierarki) peraturan perundang-undangan, maupun dari segi substansi hukumnya sehingga berpengaruh terhadap efektivitas pelaksanaan pengaturan peruntukan kawasan dalam penataan ruang di dalam masyarakat. Kondisi demikian menimbulkan berbagai implikasi, baik positif maupun negatif, baik implikasi hukum, yang salah satunya adalah implikasi politik hukum, maupun implikasi nonhukum, yakni berupa konflik hukum ${ }^{8}$ maupun konflik nonhukum sebagai implikasi negatifnya.

Berdasarkan latar belakang yang telah diuraikan, timbul pertanyaan "Bagaimanakah perubahan pengaturan peruntukan kawasan dalam hukum penataan ruang?" yang dijabarkan dalam sub-sub pertanyaan penelitian yaitu: (1) Apakah faktor-

\footnotetext{
${ }^{4}$ Pasal 22 Ayat (6) UUPR 1992

${ }^{5}$ Selanjutnya Disingkat Menjadi Perda RTRW Tahun 2001

${ }^{6}$ Disingkat RDTRK Kecamatan Klojen Tahun 20052008.

${ }^{7}$ Budihardjo, Eko. 1997. Tata Ruang Perkotaan. Bandung: Alumni, hlm. 28.

${ }^{8}$ Istilah ini diadopsi dari buku Adrian Briggs yang berjudul The Conflict of Laws, New York: Oxford University Press, 2002.
}

faktor yang mendasari dan yang menyebabkan perubahan pengaturan peruntukan kawasan dalam hukum penataan ruang di Kota Malang? (2) Bagaimanakah implikasi politik hukum atas kebijakan perubahan pengaturan peruntukan kawasan dalam hukum penataan ruang di Kota Malang? Untuk menjawab pertanyaan tersebut, dalam penelitian digunakan tipologi sosiologi hukum yang bersifat deskriptif dengan pendekatan yuridis dan empiris dalam studi kasus dengan sumber data primer dan sekunder yang dikumpulkan menggunakan metode observasi, catatan lapangan, dan wawancara yang selanjutnya dianalisis dengan menggunakan model analisis interaktif dan analisis isi.

\section{Hukum dan Fungsinya di Ruang Sosial}

Pengertian hukum penataan ruang adalah kumpulan peraturan dalam proses perencanaan tata ruang, pemanfaatan ruang, dan pengendalian pemanfaatan ruang, yang diambil dari suatu kebijakan pemerintah baik pusat maupun daerah. Hukum penataan ruang digunakan untuk mengatur dan menyejahterakan masyarakat yang berkeadilan dalam menyelenggarakan kesejahteraan sosial yang dibuat oleh lembaga yang berwenang yang berupa peraturan-peraturan yang bersifat memaksa dan memberikan sanksi bagi yang melanggarnya. Hukum untuk mengatur masyarakat ataupun aparat pemerintah sebagai penguasa, dengan fungsi meliputi: (1) Standard of conduct, yakni sandaran atau ukuran tingkah laku yang harus ditaati setiap orang dalam bertindak dalam melakukan hubungan satu dengan yang lain; (2) As a tool of social engineering, yakni sebagai sarana atau alat untuk mengubah masyarakat ke arah yang lebih baik, baik secara pribadi maupun dalam hidup masyarakat, (3) As a tool of social control, yakni sebagai alat untuk mengontrol tingkah laku dan perbuatan manusia agar tidak melakukan perbuatan yang melawan norma hukum, agama, dan susila, dan (4) As a facility on of human interaction, yakni hukum berfungsi tidak hanya untuk menciptakan ketertiban, tetapi juga menciptakan perubahan masyarakat dengan cara memperlancar proses interaksi sosial dan diharapkan menjadi pendorong untuk menimbulkan perubahan dalam kehidupan masyarakat.

Terkait dengan pengertian dan fungsi hukum tersebut, peneliti menggunakan gagasan hukum progresif dari Satjipto Rahardjo sebagai dasar teori dalam menganalisis permasalahan penelitian ini, disamping hukum responsif dari Nonet dan Selznick. Esensi dari hukum progresif adalah suatu proses yang terus-menerus hukum membangun dirinya menuju yang ideal. Gagasan hukum progresif itu untuk mencari cara mengatasi 
keterpurukan hukum di Indonesia secara lebih bermakna (significant). Bermakna di sini dalam arti pengubahan secara lebih cepat, melakukan pembalikan yang mendasar, melakukan pembebasan, terobosan, dan lain-lain.

Menurut hukum progresif, negara hukum tidak cukup jika hanya mengusung undang-undang (peraturan) dan prosedur dalam setiap penyelesaian perkara (masalah), tetapi lebih luas dari itu yakni harus melibatkan kaidah/norma, etika, dan logika. Beberapa karakter hukum progresif yang diharapkan menjadi tipe hukum yang mampu memberi jalan bagi pembangunan hukum di Indonesia pada masa mendatang. Paradigma itu meliputi (a) hukum diciptakan untuk kesejahteraan manusia, (b) pluralisme hukum, (c) sinergi atas kepentingan pusat dan daerah, (d) koordinasi, dan (e) harmonisasi hukum.

Untuk mendukung gagasan hukum progresif tersebut, dalam tataran implementasi harus dibarengi dengan adanya hukum responsif, guna menunjukkan suatu kapasitas beradaptasi yang bertanggung jawab, yaitu adaptasi yang selektif, dan tidak serampangan. Suatu institusi yang responsif mempertahankan secara kuat hal-hal yang esensial bagi integritasnya sembari tetap memerhatikan atau memperhitungkan keberadaan kekuatan-kekuatan baru dalam lingkungannya. Untuk melakukannya, hukum responsif memperkuat cara-cara dimana keterbukaan dan integritas dapat saling menopang walaupun terdapat benturan di antara keduanya.

Beberapa ciri hukum responsif adalah bertujuan agar hukum lebih tanggap terhadap kebutuhan terbuka pada pengaruh dan lebih efektif dalam menangani masalah-masalah sosial. Pertama, dinamika perkembangan hukum meningkatkan otoritas tujuan. Kedua, mengendalikan tuntutan pada ketaatan serta mengurangi kekakuan hukum. Ketiga, bantuan hukum menampilkan suatu dimensi politik. Keempat, terdapat perencanaan pranatapranata hukum secara lebih kompeten. Dengan demikian, dapat disimpulkan bahwa karakteristik produk hukum responsif/populistik merupakan produk hukum yang mencerminkan rasa keadilan dan memenuhi harapan masyarakat. Dalam proses pembuatannya memberikan peranan besar dan partisipasi penuh kelompok-kelompok sosial atau individu di dalam masyarakat. Hasilnya bersifat responsif terhadap tuntutan-tuntutan kelompok sosial atau individu dalam masyarakat. ${ }^{9}$

Terkait dengan uraian di atas, Garuda Nusantara berpendapat bahwa secara harfiah politik hukum dapat diartikan sebagai kebijakan hukum (legal

9 Mahfud, Moh. M.D..2001. Politik Hukum di Indonesia, Jakarta: Pustaka LP3ES Indonesia, hlm. 25. policy) yang hendak diterapkan atau dilaksanakan secara nasional oleh suatu pemerintahan negara tertentu, yang meliputi: (1) Pelaksanaan ketentuan hukum yang telah ada secara konsisten; (2) Pembangunan hukum yang intinya adalah pembaruan terhadap ketentuan hukum yang telah ada dan yang dianggap usang, dan penciptaan ketentuan hukum baru yang diperlukan untuk memenuhi tuntutan perkembangan yang terjadi dalam masyarakat; (3) Penegasan fungsi lembaga penegak atau pelaksana hukum dan pembinaan anggotanya, dan (4) Meningkatkan kesadaran hukum masyarakat menurut persepsi kelompok elit pengambil kebijakan. ${ }^{10}$

Politik hukum adalah kebijakan dasar penyelenggara negara dalam bidang hukum yang telah, sedang, dan akan berlaku, berdasarkan dari nilai-nilai yang diyakini masyarakat untuk mencapai tujuan negara. Kebijakan disini diartikan sebagai strategi yang sistematis, terinci, dan mendasar. Adapun prinsip good environmental governance dalam penataan ruang merupakan pisau analisis dari kebijaksanaan penataan ruang yang dijalankan oleh pemerintah, tidak terlepas dari prinsip good governance dengan objek environment (lingkungan) yang dikaitkan dengan penataan ruang yang mempunyai karakter-karakter yaitu: (1) Supremasi hukum (the supremacy of law), setiap tindakan negara harus dilandasi oleh hukum dan bukan berdasarkan diskresi (tindakan sepihak berdasarkan kekuasaan yang dimilikinya); (2) Kepastian hukum (legal certainly), yang mensyaratkan adanya jaminan bahwa suatu masalah diatur secara jelas, tegas, dan tidak duplikatif serta bertentangan dengan peraturan perundangundangan lainnya; (3) Hukum yang responsif, yang harus mampu menyerap aspirasi masyarakat luas dan mampu mengakomodasikan kebutuhan masyarakat dan bukan dibuat untuk kepentingan segelintir elit; (4) Penegakan hukum yang konsisten dan non diskriminatif, yang mensyaratkan adanya sanksi, mekanisme untuk menjalankan sanksi, dan sumber daya manusia/penegak hukum yang memiliki integritas; (5) Keberadaan independensi peradilan, yang merupakan syarat penting dalam perwujudan rule of law, yakni pada efektivitas peradilan.

Berdasarkan uraian tersebut, prinsip good environmental governance dalam penataan ruang adalah prinsip good governance yang dijalankan oleh pemerintahan berdasarkan kewenangannya dalam pengelolaan lingkungan (environment), yaitu

\footnotetext{
${ }^{10}$ Nusantara, Abdul Hakim Garuda. "Politik Hukum Nasional". Makalah dalam Kalabahu yang diselenggarakan oleh YLBHI dan LBH Surabaya, September 1985.
} 
ruang sebagai bagian dari sumber daya alam, termasuk di dalamnya sumber daya agraria.

\section{Hasil Penelitian Dan Pembahasan}

\section{Faktor yang Mendasari Perubahan Pengaturan Penataan Ruang Kota Malang}

Faktor yang mendasari perubahan pengaturan peruntukan kawasan dalam Hukum Penataan Ruang Kota Malang meliputi faktor permasalahan penataan ruang Kota Malang dan faktor deviasi RTRW terhadap kondisi eksisting di lapangan. Faktor permasalahan penataan ruang Kota Malang meliputi: (a) Faktor perubahan kondisi fisik; (b) Faktor perubahan disparitas pembangunan; (c) Faktor perubahan sistem jaringan transportasi; (d) Faktor perkembangan dan pemerataan ekonomi wilayah kota; dan (e) Faktor pengendalian dan pemanfaatan ruang.

Faktor deviasi RT RW terhadap kondisi eksisting di lapangan meliputi: (a) Faktor deviasi $R T R W$ dalam aspek kependudukan; (b) Faktor deviasi RTRW dalam aspek struktur wilayah; (c) Faktor deviasi RTRW dalam aspek pemanfaatan dan pengendalian ruang; (d) Faktor deviasi RTRW dalam aspek sistem transportasi; dan (e) Faktor deviasi RTRW dalam aspek fasilitas dan utilitas. Faktor yang menyebabkan perubahan pengaturan peruntukan kawasan dalam hukum penataan ruang Kota Malang didasarkan hasil wawancara sebelas responden terteliti yang dipilih sesuai dengan kapasitas dan pengetahuannya tentang kasus-kasus yang menjadi objek penelitian ini.

Faktor yang menyebabkan perubahan pengaturan peruntukan kawasan dalam hukum penataan ruang Kota Malang dapat diklasifikasikan menjadi faktor hukum dan faktor non hukum. Faktor hukum adalah faktor yang menyebabkan perubahan pengaturan peruntukan kawasan dalam hukum penataan ruang Kota Malang yang diatur berdasarkan peraturan perundang-undangan yang berlaku. Sedangkan faktor non hukum adalah faktor yang menyebabkan perubahan pengaturan peruntukan kawasan dalam hukum penataan ruang Kota Malang yang tidak terkait langsung dengan hukum, seperti faktor politik, ekonomi, sosial, dan budaya. Dalam implementasinya, faktor-faktor tersebut selalu memengaruhi hukum sehingga keseluruhannya merupakan serangkaian faktor yang memengaruhi pilihan hukum dalam hukum penataan ruang. Pilihan hukum itu merupakan politik hukum dalam suatu penerbitan peraturan perundang-undangan dan kebijakan suatu pemerintahan, dalam penelitian ini Pemerintahan Kota Malang.

Berdasarkan klasifikasi di atas, kultur hukum merupakan faktor tertinggi yang menyebabkan perubahan pengaturan peruntukan kawasan, yakni
30 faktor atau $24,79 \%$, sedangkan dalam faktor nonhukum, yaitu faktor sosial yang tertinggi, yakni sebanyak 17 faktor atau 14\%. Untuk kombinasi faktor hukum dengan hukum, yang tertinggi faktor kombinasi substansi hukum dengan kultur hukum sebanyak 13 faktor atau $10,7 \%$. Sedangkan kombinasi faktor hukum dengan non hukum, yang tertinggi adalah faktor kombinasi kultur hukum dengan politik sebanyak 4 faktor atau 3,3\%. Kemudian kombinasi faktor non hukum dengan non hukum, yang tertinggi kombinasi sosial dengan lingkungan sebanyak 2 faktor atau 1,6\%.

\section{Implikasi Politik Hukum dalam Hukum Penataan Ruang Kota Malang}

Pilihan perubahan pengaturan peruntukan kawasan dalam hukum penataan ruang merupakan pilihan kebijakan yang diatur dalam peraturan perundang-undangan antara lain dalam UUPR 1992 disebutkan dalam Pasal 13 Ayat (2) dengan jangka waktu tertentu Pasal 22 Ayat (5) sedangkan dalam Perda RTRW Kota Malang Nomor 7 Tahun 2001, jangka waktu disebutkan dalam Pasal 55 dan Pasal 60.

Perubahan pengaturan kawasan dalam UUPR 1992 mengandung kepastian hukum. Meskipun jangka waktunya belum lima tahun sejak ditetapkan, namun adanya perubahan di lapangan, Perda RTRW Kota Malang Tahun 2001 telah mereduksi kepastian hukum tersebut. Perubahan itu antara lain melalui Keputusan DPRD Kota Malang Nomor 47 Tahun 2002 tentang Persetujuan Evaluasi/Revisi Peraturan Daerah Kota Malang Nomor 7 Tahun 2001 tentang Rencana Tata Ruang Wilayah Kota Malang Tahun 2001-2011 tanggal 3 Desember 2002. Disamping ada fakta perubahan peruntukan kawasan, seperti kawasan pendidikan di lahan eks-APP, namun sekarang telah menjadi kawasan perdagangan dan jasa skala regional, yakni dengan berdirinya pusat perbelanjaan dan perdagangan Malang Town Square (MATOS), kawasan ruang terbuka hijau di kawasan Stadion Gajayana Malang yang dibangun hotel, pusat perbelanjaan, dan lain-lain, telah menghilangkan lebih dari 3 hektar fungsi penyerapan dan ruang terbuka hijau pada kawasan tersebut.

Berdasarkan uraian di atas, kebijakan perubahan pengaturan peruntukan kawasan belum mendasarkan pada konsep good inveronmental governance. Bahkan kebijakan tersebut telah kehilangan landasan filosofisnya, yakni pengaruh atau legitimasi dari masyarakat sebagai tempat hukum tersebut diberlakukan. Kondisi demikian dapat diamati dari tidak dilaksanakannya perubahan pengaturan peruntukan kawasan secara konsisten seperti penerbitan Peraturan Walikota Malang Nomor 33 Tahun 2005 tentang RDTKR 
Kecamatan Klojen Tahun 2005 - 2008 yang dalam substansi pengaturannya merupakan perubahan dari Perda RTRW Tahun 2001.

Ditinjau dari Teori Friedman, yakni struktur hukum tidak menjalankan fungsi hukum dengan benar (ditinjau dari konsep good inveronmental governance), sehingga mempengaruhi konsistensi pemberlakuan substansi hukum. Dalam kultur hukum masyarakat Kota Malang pun ada kecenderungan bahwa Perda RTRW Nomor 7 Tahun 2001 tersebut telah kehilangan daya ikat dan/atau telah kehilangan legitimasinya, yakni dengan tidak dipatuhinya peruntukan kawasan dalam kegiatan-kegiatan pembangunan, baik oleh pihak pemerintah maupun oleh masyarakat, terutama oleh pelaku bisnis. Dasar pertimbangan kebijakan tersebut sangat bertolak belakang dengan dasar tujuan penataan ruang sebagaimana diatur dalam Pasal 3 UUPR 1992.

Dalam tataran praktik, tujuan penataan ruang dalam Pasal 4 Perda RTRW Tahun 2001 tidak dijadikan dasar pertimbangan sehingga kebijakan pilihan substansi perubahan pengaturan peruntukan kawasan didominasi atas pertimbangan investasi dan dunia usaha, seperti perubahan kawasan Matos, perubahan kawasan APP Tanjung, perubahan kawasan Stadion Gajayana, dan mengabaikan tujuan-tujuan lain, baik yang diatur dalam UUPR 1992 maupun dalam Perda RTRW Nomor 7 Tahun 2001 sehingga kebijakan pilihan substansi perubahan pengaturan peruntukan kawasan bertentangan dengan peraturan perundangundangan.

Sebagian besar lokasi yang telah berubah peruntukannya sejak tahun 2001 merupakan kawasan ruang terbuka hijau yang berfungsi sebagai penyerapan, tandon air pada musim penghujan, dan daerah tangkapan air yang merupakan sumber mata air tanah yang sehat bagi masyarakat Kota Malang. Karenanya kebijakan perubahan pengaturan yang demikian sangat bertentangan dengan tujuan terselenggaranya pemanfaatan ruang wilayah yang berkelanjutan dan berwawasan lingkungan serta perlindungan fungsi ruang dan mencegah serta menanggulangi dampak negatif terhadap lingkungan.

Secara substansi, ruang hanya dipandang sebagai objek perubahan pengaturan dalam suatu subsistem lingkungan dan agrarian. Untuk kepentingan sesaat, seperti kepentingan politik, kepentingan bisnis, dan kepentingan-kepentingan yang lain, pelestarian lingkungan sebagai sumber daya alam yang harus dilindungi oleh negara. Kepentingan-kepentingan tersebut pada tataran praktik sangat merusak ekosistem kota dan pola perilaku sosial lainnya, sehingga akhirnya merusak peradaban Kota Malang yang sudah dibangun dalam rangka semboyan Tribina Cita Kota Malang. Fakta di lapangan menunjukkan adanya perebutan peruntukan kawasan sehingga pilihan substansi perubahan pengaturan sangat bertentangan dengan kepentingan sosial yang dalam bahasa Friedman disebut sebagai kultur hukum masyarakat.

Ditinjau dari konsep hukum progresif dan hukum responsif, kebijakan pilihan substansi perubahan pengaturan peruntukan kawasan di Kota Malang dapat dikatakan belum menunjukkan adanya konsistensi terhadap substansi Perda RTRW Tahun 2001 sehingga kebijakan pilihan perubahan pengaturan tersebut yang secara substansi bertentangan dengan Perda RTRW Tahun 2001 yang masih berlaku menunjukkan bahwa pilihan substansi perubahan pengaturan belum sesuai dengan konsep hukum progresif dan hukum responsif.

Kebijakan pilihan bentuk perubahan pengaturan peruntukan kawasan dalam hukum penataan ruang Kota Malang dapat berupa perubahan perda dengan perda, perubahan perda dengan Keputusan DPRD, dan perubahan perda dengan keputusan dan peraturan walikota.

Kebijakan pilihan bentuk perubahan pengaturan peruntukan kawasan dalam hukum penataan ruang Kota Malang, yakni perubahan Peraturan Daerah Kotamadya Dati II Malang No. 8 Tahun 1995 tentang Rencana Tata Ruang Wilayah Kotamadya Dati II Malang Tahun 1992/1994-2003/2004 menjadi Peraturan Daerah Kota Malang Nomor 7 Tahun 2001 tentang Rencana Tata Ruang Wilayah Kota Malang Tahun 2001-2011 berdasarkan tata urutan perundang-undangan sebagaimana diatur dalam UU No. 10 Tahun 2004 sesuai dengan ketentuan tersebut karena terdapat kesejajaran bentuk dan kesejajaran substansi yang diatur sehingga perubahan peraturan yang kemudian mencabut dan menghapus peraturan yang terdahulu. Perubahan tersebut dapat dilihat bab atau bagian penutup dalam suatu peraturan.

Jika dicermati lebih lanjut terdapat perbedaan antara kedua pencabutan perda tersebut. Dalam Perda 8 Tahun 1995 dengan tegas Perda 3 Tahun 1990 dinyatakan dicabut dan tidak berlaku lagi, sedangkan dalam Perda 7 Tahun 2001 hanya menyebutkan Perda No. 8 Tahun 1995 dinyatakan tidak berlaku lagi dan tidak secara tegas dicabut sehingga pernyataan yang tidak tegas tersebut dalam tataran praktik digunakan untuk melakukan perubahan pengaturan perubahan peruntukan kawasan dengan Keputusan DPRD Kota Malang No. 47 Tahun 2002 tentang Persetujuan Evaluasi/Revisi Peraturan Daerah Kota Malang Nomor 7 Tahun 2001 tentang Rencana Tata Ruang Wilayah Kota Malang Tahun 2001-2011 Tanggal 3 Desember 2002. 
Tulus Wahjuono, Perubahan Pengaturan Peruntukan Kawasan...| 171

Ketidaktegasan pernyataan pencabutan Perda No. 7 Tahun 2001 dapat dilihat pula dengan tidak tegasnya peraturan daerah yang dinyatakan tidak berlaku lagi, yakni dengan kalimat “... sehingga Peraturan Daerah tentang Rencana Tata Ruang Wilayah Kota Malang tahun 1993/1994-2003/2004 dinyatakan tidak berlaku lagi." Dalam pernyataan tersebut tidak tegas nomor perda yang dicabut dan tidak lengkapnya 'identitas' perda yang dicabut, yang seharusnya berbunyi, "Peraturan Daerah ini mulai berlaku pada tanggal ditetapkan, sehingga Peraturan Daerah Kotamadya Dati II Malang No. 8 Tahun 1995 tentang Rencana Tata Ruang Wilayah Kotamadya Dati II Malang Tahun 1992/1994-2003/2004 dinyatakan dicabut dan tidak berlaku lagi."

Ditinjau dari teori Friedman, Perda No. 7 Tahun 2001 dalam tataran praktik tidak memenuhi substansi hukum, struktur hukum, maupun kultur hukum sehingga menurut Teori Friedman tidak efektif dilaksanakan. Ditinjau dari prinsip good environmental governance dalam Hukum Penataan Ruang di Kota Malang, belum dapat dilaksanakan prinsip good environment governance secara konsisten.

Ditinjau dari konsep hukum progresif dan hukum responsif, kebijakan pilihan bentuk perubahan pengaturan peruntukan kawasan di Kota Malang perda dengan perda dapat dikatakan belum menunjukkan adanya konsistensi yang jelas antara satu perubahan perda dengan perubahan perda yang lain sebagaimana telah diuraikan di atas, dengan kata lain perubahan pengaturan tersebut belum sesuai dengan konsep hukum progresif dan hukum responsif.

Kebijakan pilihan bentuk perubahan pengaturan peruntukan kawasan dalam hukum penataan ruang Kota Malang, yakni perubahan Peraturan Daerah Kotamadya Daerah Tingkat II Malang No. 8 Tahun 1995 tentang Rencana Tata Ruang Wilayah Kotamadya Daerah Tingkat II Malang Tahun 1993/1994-2003/2004 yang diubah dengan Keputusan DPRD Kotamadya Daerah Tingkat II Malang No. 11 Tahun 1998 tentang Persetujuan Diadakan Evaluasi dan Revisi Peraturan Daerah Kotamadya Daerah Tingkat II Malang Nomor 8 Tahun 1995 tentang Rencana Tata Ruang Wilayah Kotamadya Daerah Tingkat II Malang Tahun 1993/1994-2003/2004 dan perubahan Peraturan Daerah Kota Malang Nomor 7 Tahun 2001 tentang Rencana Tata Ruang Wilayah Kota Malang Tahun 2001-2011 yang diubah dengan Keputusan DPRD Kota Malang Nomor 47 Tahun 2002 tentang Persetujuan Evaluasi/Revisi Peraturan Daerah Kota Malang Nomor 7 Tahun 2001 tentang Rencana Tata Ruang Wilayah Kota Malang Tahun 2001-2011, kedua pilihan bentuk perubahan tersebut merupakan konsekuensi dari pelaksanaan kewenangan DPRD sebagai salah satu institusi pembuat peraturan daerah ${ }^{11}$. Berdasarkan kewenangan yang ada pada DPRD tersebut, secara hukum kebijakan pilihan bentuk perubahan pengaturan peruntukan kawasan dalam hukum penataan ruang Kota Malang dengan Keputusan DPRD Kota Malang dapat dibenarkan sesuai dengan peraturan perundang-undangan, tetapi konsekuensi perubahan tersebut, seharusnya terbatas mengikat pada institusi DPRD Kota Malang saja, karena bentuk dari perubahan pengaturan tersebut berupa Keputusan DPRD Kota Malang. Sebagai suatu bentuk pengaturan, suatu keputusan hanya mengikat ke dalam dan pihakpihak yang terkait dengan keputusan tersebut. Dalam penelitian ini bentuk perubahan pengaturan berupa Keputusan DPRD Kota Malang dilandasi dasar pertimbangan surat dari Walikota Malang. Untuk Keputusan DPRD Kota Malang No. 11 Tahun 1998 berdasarkan Surat Walikotamadya KDH Tingkat II Malang tanggal 12 Juni 1998 Nomor 5931/985/428.401/1998 perihal Usulan Perubahan Peruntukan Kawasan APP, sedangkan Keputusan DPRD Kota Malang Nomor 47 Tahun 2002 didasarkan pada Surat Walikota Malang Tanggal 30 Mei 2002 Nomor 050/736/420123/2002 perihal Penataan dan Peruntukan Tanah Eks-APP Kelurahan Bareng Kecamatan Klojen Kota Malang dan Surat Walikota Malang tanggal 17 Juni 2002 Nomor 620/853/420-402/2002 perihal Perubahan Fungsi Jalan di Kawasan Perumnas Malang serta surat Walikota Malang Tanggal 13 September 2002 Nomor 650/1463/420-402/2002 perihal Pembangunan Prasarana Jalan di Lokasi Perumnas Sawojajar I.

Berdasarkan landasan surat Walikota Malang tersebut terdapat keterhubungan maksud dari diterbitkannya Keputusan DPRD Kota Malang, walaupun secara hierarki perubahan pengaturan berupa perda dengan menggunakan keputusan DPRD tidak mempunyai landasan hukum karena ketidaksejajaran hierarki bentuk peraturan tersebut, dalam arti perubahan tersebut tidak sah, paling tidak perubahan tersebut cacat yuridis.

Fakta yang didapat dalam tataran praktik, bentuk Keputusan DPRD Kota Malang merupakan bentuk kesepakatan awal akan adanya perubahan pengaturan peruntukan kawasan yang merupakan 'perjanjian' tidak tertulis atau suatu konvensi di daerah dengan Walikota Malang. Konvensi itu banyak sekali dilakukan terutama, ketika walikota hendak menerbitkan suatu kebijakan yang tidak populer di masyarakat sehingga terkesan Keputusan

\footnotetext{
${ }^{11}$ UU No. 22 Tahun 1999 jo. UU No. 32 Tahun 2004
} Jo. UU No. 8 Tahun 2005 tentang Pemerintahan Daerah. 
DPRD Kota Malang merupakan stempel bagi keabsahan kebijakan yang tidak populer tersebut.

Contoh lain, perubahan Perda No. 7 Tahun 2001 yang diubah dengan Keputusan DPRD Kota Malang Nomor 28 Tahun 2005 tentang Persetujuan DPRD Kota Malang atas Rencana Detail Tata Ruang Kota Kecamatan Klojen Tahun 2005-2008 dan Keputusan DPRD Kota Malang Nomor 29 Tahun 2005 tentang Persetujuan Perjanjian Kerja Sama antara Pemkot Malang dengan PT Mustika Taman Olympic tentang Pembangunan dan/atau Renovasi Stadion Gajayana Kota Malang. Kedua perubahan pengaturan tersebut merupakan kebijakan Walikota Malang yang tidak populer di masyarakat sehingga dalam memutuskan kedua Keputusan DPRD Kota Malang tersebut, pihakpihak tertentu yang mempunyai kepentingan, baik kepentingan bisnis, politik, maupun kepentingan lain, menggunakan 'jasa preman' sebagai bagian dari intimidasi maupun pressure agar putusan tersebut berjalan lancar. Fakta di lapangan yang diamati peneliti menguatkan pendapat tersebut, di samping pendapat beberapa responden yang diwawancarai peneliti dalam penelitian ini, sebagaimana telah disebutkan dalam faktor-faktor yang menyebabkan perubahan pengaturan peruntukan kawasan.

Kebijakan pilihan bentuk perubahan pengaturan peruntukan kawasan dalam hukum penataan ruang Kota Malang, yakni perubahan Perda Kota Malang Nomor 7 Tahun 2001 tentang Rencana Tata Ruang Wilayah Kota Malang Tahun 2001-2011 yang diubah dengan Keputusan Walikota Malang Nomor 214 Tahun 2003 tentang Rencana Detail Tata Ruang Kota Kecamatan Blimbing Kota Malang tahun 2003-2008, dan Keputusan Walikota Malang Nomor 196 Tahun 2004 tentang Rencana Detail Tata Ruang Kota Kecamatan Kedungkandang Kota Malang tahun 2004-2009, serta Peraturan Walikota Malang Nomor 33 Tahun 2005 tentang Rencana Detail Tata Ruang Kota Kecamatan Klojen Tahun 2005-2008.

Sebagaimana diatur dalam UU No. 32 Tahun 2004 tentang Pemerintahan Daerah Pasal 146 Ayat (1) disebutkan bahwa untuk melaksanakan perda dan atas kuasa peraturan perundang-undangan, Kepala Daerah menetapkan Peraturan Kepala Daerah dan atau Keputusan Kepala Daerah. Berdasarkan ketentuan tersebut, seharusnya Peraturan dan Keputusan Walikota Malang sebagaimana disebutkan di atas diterbitkan untuk melaksanakan Perda RTRW Kota Malang No. 7 Tahun 2001. Di samping untuk melaksanakan Perda, dalam ayat (2) disebutkan bahwa keputusan dan peraturan kepala daerah itu dilarang bertentangan dengan kepentingan umum, perda, dan peraturan perundang-undangan yang lebih tinggi.

Dalam tataran praktik penerbitan Peraturan Walikota Malang Nomor 33 Tahun 2005 tentang Rencana Detail Tata Ruang Kota Kecamatan Klojen Tahun 2005-2008 secara substansi bertentangan dengan Perda RTRW Kota Malang No. 7 Tahun 2001. Dengan demikian, kebijakan pilihan bentuk perubahan perda dengan peraturan dan keputusan walikota Malang bertentangan dengan peraturan perundang-undangan yang lebih tinggi. Jika terjadi konflik hukum yang demikian, asas hukum 'lex superiori derogat legi inferiori' yang harus diterapkan, yakni peraturan yang lebih tinggi menghapus peraturan yang lebih rendah derajatnya.

Ditinjau dari Teori Kelsen tentang hierarki peraturan perundang-undangan, penerbitan Peraturan Walikota Malang Nomor 33 Tahun 2005 tentang Rencana Detail Tata Ruang Kota Kecamatan Klojen Tahun 2005-2008 yang bertentangan dengan Perda RTRW Kota Malang No. 7 Tahun 2001 adalah tidak sah dan harus dicabut atau direvisi guna menghilangkan dualisme substansi peraturan perundang-undangan yang saling bertolak belakang dengan derajat peraturan perundang-undangan yang tidak sama tersebut.

Kondisi demikian sangat menyulitkan pelaksanaan pembangunan di lapangan, terutama pelaksanaan penegakan hukum baik yang dilakukan oleh Satuan Polisi Pamongpraja (Satpol PP) maupun oleh penegak hukum lainnya. Implikasinya, tidak ada kepastian hukum dalam hukum penataan ruang di Kecamatan Klojen. Pendapat demikian dikuatkan dengan praktik di lapangan yang diamati peneliti, seperti pembangunan Mall Olympic Garden (MOG) di Stadion Gajayana yang mengubah peruntukan sekitar $30.000 \mathrm{~m}^{2}$ (3 hektar) dari luasan $87.500 \mathrm{~m}^{2}$ kawasan ruang terbuka hijau berupa penyerapan dan kawasan lapangan olah raga untuk kawasan komersial dengan pembangunan mall, hotel, dan pusat perdagangan lainnya. Pembangunan MOG banyak ditentang oleh masyarakat karena bertentangan dengan UU No. 3 Tahun 2005 tentang Olahraga, maupun peraturan perundang-undangan lainnya, tetapi Pemerintah Kota Malang tetap bersikukuh melaksanakan pembangunan MOG, walaupun pembangunan tersebut bertentangan dengan peraturan perundang-undangan, walaupun jika tidak terdapat faktor kepentingan yang mempengaruhi, kebijakan tersebut sangat mungkin untuk diubah oleh Pemkot Malang dengan memperhatikan kebutuhan kesejahteraan masyarakat.

Pada tanggal 26 April 2007 telah diundangkan dan diberlakukan Undang-Undang No. 26 Tahun 
2007 tentang Penataan Ruang (UUPR 2007). Dalam UUPR 2007 Pasal 79 dengan tegas mencabut dan menyatakan tidak berlaku lagi pengaturan penataan ruang dalam Undang-Undang No. 24 Tahun 1992. Dengan dicabutnya UUPR 1992, terdapat implikasi-implikasi terhadap pengaturan penataan ruang di daerah yang mendasarkan pada UUPR 1992 tersebut.

Berdasarkan UUPR 2007 Pasal 76, Perda Kota Malang No. 7 Tahun 2001 masih tetap berlaku sepanjang tidak bertentangan dan belum diganti dengan UUPR 2007 tersebut. Pasal 78 Ayat (4) huruf c, Perda RTRW Kota Malang Tahun 2001 dapat dilakukan revisi dengan cara menyusun Perda RTRW baru yang mengubah Perda RTRW Tahun 2001 atau dengan cara menyesuaikan Perda RTRW 2001 dengan UUPR 2007 tersebut paling lambat 3 (tiga) tahun terhitung sejak UUPR 2007 diberlakukan.

Terdapat substansi perubahan politik hukum dalam UUPR 2007 terhadap UUPR 1992 yang sangat signifikan adalah pasal-pasal tentang hak dan kewajiban. Konstruksi penulisan pasal dan ayat tentang hak dan kewajiban dalam UUPR 1992 lebih lebih sedikit dan lebih ringkas dengan materi penjelasan undang-undang yang lebih luas dan detail yang memungkinkan lebih luasnya hak-hak yang diberikan kepada masyarakat, baik hak-hak perorangan maupun hak-hak sosial. Sedangkan dalam UUPR 2007, kontruksi penulisan pasal dan ayat tentang hak dan kewajiban lebih banyak dan detail dengan penjelasan yang singkat-singkat sehingga pasal dan ayat tersebut menjadi rigid (kaku) dan lebih mempersempit hak-hak masyarakat, yakni hanya hak-hak yang secara eksplisit (tersurat) sebagaimana diatur dalam UUPR 2007 sedangkan hak-hak lain tentang penataan ruang menjadi terabaikan.

Terkait dengan UUPR 2007, peran serta masyarakat dalam Perda RTRW Kota Malang Tahun 2001, menurut peneliti merupakan peran masyarakat sebagaimana diatur dalam UUPR 2007. Hal tersebut dapat dilihat dari konstruk penulisan maupun konstruk substansinya. Di samping itu, dalam Perda RTRW Kota Malang Tahun 2001 Pasal 47 terdapat ketentuan administrasi yang tidak diatur dalam UUPR 1992 sedangkan dalam UUPR 2007 diatur tentang sanksi administratif. Ketentuan administrasi dalam Perda RTRW Tahun 2001 secara substansi hampir sama dengan sanksi administratif dalam UUPR 2007 sehingga diperlukan penyesuaian-penyesuaian, baik dari segi substansi hukum maupun definisi ketentuan. Berdasarkan penyesuaian tersebut pelaksanaan penataan ruang dalam UUPR 2007 dapat segera terealisasi dalam Perda RTRW Kota Malang.
Hal lain yang perlu diatur dalam Perda RTRW Kota Malang adalah ketentuan pidana sebagai pelaksanaan dari ketentuan pidana dalam UUPR 2007. Hal tersebut juga sebagai perbaikan pelaksanaan penataan ruang Perda RTRW Kota Malang Tahun 2001 yang tidak efektif dilaksanakan karena tidak jelas sanksi pidananya.

Berdasarkan uraian di atas, dengan diundangkannya UUPR 2007, Perda RTRW Kota Malang Tahun 2001 perlu dilakukan revisi atau penyesuaian-penyesuaian, baik dari segi substansi hukum maupun definisi-definisi hukum yang berubah. Revisi atau penyesuaian tersebut harus dilakukan berdasarkan hasil evaluasi yang menyeluruh terhadap pelaksanaan Perda RTRW Kota Malang Tahun 2001.

\section{Pilihan Solusi Atas Implikasi Politik Hukum Terhadap Kebijakan Perubahan Pengaturan Peruntukan Kawasan dalam Hukum Penataan Ruang Kota Malang}

Pilihan solusi atas implikasi politik hukum terhadap kebijakan perubahan pengaturan peruntukan kawasan dalam hukum penataan ruang Kota Malang yang dapat diusulkan dalam penelitian ini sebagai berikut. a) Mencabut dan atau merevisi Perda RTRW Kota Malang No. 7 Tahun 2001 dan peraturan pelaksanaan di bawahnya, antara lain Peraturan Walikota Malang No. 33 Tahun 2005 tentang RDTRK Kecamatan Klojen Tahun 2005 - 2008 karena sudah kehilangan legitimasinya baik secara filosofis, yuridis maupun sosilogis dan menerbitkan serta mengonstruk Perda RTRW Kota Malang dan peraturan pelaksanaan di bawahnya yang sesuai dengan prinsip-prinsip good environmental governance, konsep hukum progresif dan responsif dengan jalan menghilangkan faktor-faktor negatif, baik faktor hukum maupun faktor nonhukum yang menyebabkan perubahan pengaturan peruntukan kawasan dalam hukum penataan ruang sebagaimana terungkap dalam penelitian ini sebagai upaya evaluasi konstruktif terhadap fakta sosiologi hukum yang ada dan terjadi di masyarakat; b) Melakukan penegakan hukum terhadap pelanggaran-pelanggaran yang terjadi beserta perangkat-perangkatnya atas Perda RTRW Kota Malang No. 7 Tahun 2001 sehingga kondisi hukum yang diimplementasikan dalam bentuk pengaturan penataan ruang kembali sesuai dengan kehendak keadilan, yakni dengan adanya kepastian hukum sebagai salah satu karakteristik suatu hukum, di samping asas keberlanjutan (sustainable) suatu pembangunan kota; c) Ditinjau dari kondisi peraturan perundang-undangan penataan ruang Kota Malang yang satu dengan lain tidak sinkron maka perlu adanya sinkronisasi peraturan 
perundang-undangan baik dari segi hierarki, substansi, bentuk, maupun pelaksanaan dari peraturan perundang-undangan tersebut sehingga memenuhi kriteria konsep good environment governance dan rule expectation sebagaimana diharapkan oleh masyarakat, serta untuk menghindari sekecil mungkin penerbitan suatu kebijakan yang 'memakan korban' terpecahnya masyarakat menjadi pro dan kontra yang akibatnya terjadi gesekan-gesekan kepentingan di dalam masyarakat yang akhirnya menjadi kontra produktif dalam pelaksanaan pembangunan, terutama dalam kaitannya dengan perubahan pengaturan peruntukan kawasan dalam hukum penataan ruang; d) Memberi peran yang lebih besar kepada masyarakat sebagai bagian dari hak partisipasi masyarakat atas kebutuhan ruang kota sesuai dengan harapan serta kebutuhan sosialnya dengan jalan membuka ruang publik yang luas kepada masyarakat untuk melakukan evaluasi serta kritik yang membangun demi tujuan bersama, yakni terciptanya Tri Bina Cita Kota Malang yang selama ini terkesan 'dipasung' oleh Pemerintah Kota Malang.

\section{Kesimpulan}

Faktor yang mendasari perubahan pengaturan peruntukan kawasan dalam hukum penataan ruang Kota Malang meliputi faktor permasalahan penataan ruang Kota Malang dan faktor deviasi RTRW terhadap fakta di lapangan, sedangkan faktor yang menyebabkan perubahan pengaturan peruntukan kawasan dalam hukum penataan ruang Kota Malang terdapat faktor hukum dan faktor nonhukum, baik positif maupun negatif yang merupakan serangkaian faktor yang memengaruhi pilihan hukum atas kebijakan perubahan pengaturan peruntukan kawasan dalam hukum penataan ruang di Kota Malang.

\section{DAFTAR RUJUKAN}

\section{BUKU}

Asshiddiqie, Jimly dan M. Ali Syafaat. 2006. Teori Hans Kelsen tentang Hukum. Jakarta: Konstitusi Press.

Briggs, Adrian. 2002. The Conflict of Laws, New York: Oxford University Press.

Budihardjo, Eko. 1997. Tata Ruang Perkotaan, Bandung: Alumni

Friedman, L.M. 1975.The Legal System: A Social Science Perspective. New York: Russel Sage Foundation. mplikasi politik hukum atas kebijakan perubahan pengaturan peruntukan kawasan dalam hukum penataan ruang Kota Malang mengindikasikan belum mendasarkan pada prinsip good environmental governance sehingga produk hukum yang dihasilkan belum memenuhi konsep hukum progresif dan hukum responsif serta kehilangan legitimasinya, baik secara filosofis, yuridis maupun sosiologis di dalam masyarakat.

\section{Saran-Saran}

Hasil penelitian ini dapat dijadikan sarana sumber informasi dalam merencanakan kegiatan perubahan pengaturan peruntukan kawasan dalam bentuk Perda RTRW Kota Malang dan peraturan perundang-undangan di bawahnya, seperti RDTRK, RTRK dan lain-lain peraturan perundang-undangan yang terkait dengan penataan ruang di Kota Malang.

Bagi para peneliti, disarankan penelitian seperti ini dilanjutkan dengan aspek-aspek kajian yang lainnya, seperti hak-hak masyarakat yang tidak diakomodasi dalam UUPR 2007, mengelaborasi perubahan Perda No. 2 Tahun 2006 tentang RTRW Provinsi Jawa Timur, menganalisis kebijakan yang koruptif dari birokrat yang represif sehingga ke depan peluang korupsi terhadap implementasi Perda yang terkait dengan perubahan pengaturan peruntukan kawasan dalam hukum penataan ruang dapat dibatasi dan dikontrol.

Bagi Pemerintahan Kota Malang (Pemerintah dan DPRD Kota Malang) perlu segera melakukan kebijakan sebagaimana diuraikan dalam pilihan solusi atas implikasi politik hukum terhadap kebijakan perubahan pengaturan peruntukan kawasan dalam hukum penataan ruang Kota Malang.

Kelsen, Hans. 2006. General Theory of Law and State. Terjemahan Raisul Muttaqien. Bandung: Nusamedia \& Nuansa.

Mahfud, Moh. M.D. 2001. Politik Hukum di Indonesia, Jakarta: Pustaka LP3ES Indonesia.

Nusantara, Abdul Hakim Garuda. "Politik Hukum Nasional". Makalah dalam Kalabahu yang diselenggarakan oleh YLBHI dan LBH Surabaya, September 1985. 
Tulus Wahjuono, Perubahan Pengaturan Peruntukan Kawasan...| 175

Sumardjono, Maria S.W. 2005. Kebijakan Pertanahan: Antara Regulasi dan Implementasi. Jakarta: Kompas.

PERATURAN PERUNDANG-UNDANGAN

Undang-undang Nomor 5 Tahun 1960 tentang Peraturan Dasar Pokok-Pokok Agraria (Lembaran Negara Tahun 1960 Nomor 104, Tambahan Lembaran Negara Nomor 2043).

Undang-undang No.24 Tahun 1992 tentang Penataan Ruang.

Undang-undang No. 22 Tahun 1999 tentang Pemerintahan Daerah

Undang-undang No. 32 Tahun 2004 tentang Pemerintahan Daerah

Undang-undang No. 8 Tahun 2005 tentang Perubahan Undang-undang No. 32 Tahun 2004 tentang Pemerintahan Daerah.

Undang-undang No.26 Tahun 2007 tentang Penataan Ruang.

Peraturan Daerah Kota Malang No. 7 Tahun 2001 tentang RTRW Kota Malang Tahun 2001-2011.

Peraturan Walikota Malang No. 33 Tahun 2005 tentang RDTRK Kecamatan Klojen Tahun 2005-2008. 